Review

\title{
Comparison of Prognostic MicroRNA Biomarkers in Blood and Tissues for Gastric Cancer
}

\author{
Wenying Yan ${ }^{1}$ 2,3, Laijun Qian 4 , Jiajia Chen ${ }^{5}$, Weichang Chen ${ }^{\circledR}$ and Bairong Shen ${ }^{\circledR}$ \\ 1. Department of Gastroenterology, The First Affiliated Hospital of Soochow University, Suzhou 215006, China; \\ 2. Taicang Center for Translational Bioinformatics, Taicang 215400, China; \\ 3. Center for Systems Biology, Soochow University, Suzhou 215006, China; \\ 4. Daibu Center Hospital, Liyang, 213330, China; \\ 5. School of Chemistry, Biology and Material Engineering, Suzhou University of Science and Technology, Suzhou 215011, China.
}

$\bowtie$ Corresponding authors: Professor Bairong Shen, email: bairong.shen@suda.edu.cn or to Professor Weichang Chen, email: weichangchen@126.com () Ivyspring International Publisher. Reproduction is permitted for personal, noncommercial use, provided that the article is in whole, unmodified, and properly cited. See http://ivyspring.com/terms for terms and conditions.

Received: 2015.07.26; Accepted: 2015.10.18; Published: 2016.01.01

\begin{abstract}
Gastric cancer (GC) still keeps up high mortality worldwide with poor prognosis. Efficient and non-invasive prognostic biomarkers are urgently needed. MicroRNAs are non-coding RNAs playing roles in post-transcriptional gene regulation, which contribute to various biological processes such as development, differentiation and carcinogenesis. MicroRNA expression profiles have been associated with the prognosis and outcome in GC. MicroRNA prognostic biomarkers have been identified from blood or tissues samples, but with different prognostic features. Understanding the various roles of microRNAs in different sample sources of GC will provide deep insights into GC progression. In this review, we highlight the distinct prognostic roles of microRNAs biomarkers in blood and tissue according to their relationships with prognostic parameters, survival rates and target pathways. This will be useful for non-invasive biomarker development and selection in prognosis of GC.
\end{abstract}

Key words: blood, gastric cancer, microRNA, prognostic biomarker, tissues

\section{Introduction}

Gastric cancer (GC) or stomach cancer (SC) is highly heterogeneous in histological pattern, biological behavior, outcome and biomarkers. It is the fourth common cancer and the second major contributor to cancer mortality worldwide $[1,2]$. Although the incidence and mortality of GC declined in the last decades because of the improvement in surgical and adjuvant multimodal treatment approaches, the overall prognosis for advanced GC remains poor and the 5 -year survival rate for advanced GC is still low between $10 \%$ and $25 \%[3,4]$. New prognostic biomarkers for GC are extremely needed.

MicroRNAs are small non-coding RNAs (18-25 nucleotides) and changes in the abundance of them reveal promising prognostic associations with major cancer outcome such as clinicopathological features and survival rates. Many works have demonstrated that microRNAs could be as potential biomarkers in different diseases, such as prostate cancer, clear cell renal cell carcinoma, sepsis, gastric cancer and so on [5-8]. In GC, several reports have reviewed the microRNAs as biomarkers for GC from different perspectives. Shrestha et al. and Wang et al. focused on the systematic summarizing microRNA expression profile from 6 studies and 14 studies in gastric cancer tissues, respectively $[9,10]$. Li and her colleagues overviewed the epigenetic biomarkers including DNA methylation, histone modification and microRNAs in gastrointestinal cancers [11]. Another review also summarized the epigenetic biomarkers, DNA methylation and microRNAs, but only paid attention to their function as diagnostic markers in body fluids [12]. A meta-analysis was performed on circulating microRNAs in 22 studies and concluded 
that miR-21 can be a biomarker for detection of GC with $\mathrm{AUC}=0.91$ and $\mathrm{Q}=0.8466$ [13]. Most of the comprehensive reviews summarized the microRNAs function and the role of microRNAs as markers for GC diagnosis, prognosis or therapeutic response [14-20]. But the different prognostic roles of microRNAs in blood and tissues remain poorly understood, which is much more important to the understanding of the clinical roles of these microRNAs in different sample sources.

In this review, we give an elaborate comparison of microRNAs as prognostic biomarkers in blood and tissues. MicroRNA biomarkers in tissues indicate the samples from tissues of patients while microRNA biomarkers in blood indicate the samples from serum, plasma, or blood. We selected the studies by the search criteria "(gastric cancer OR stomach cancer) AND (biomarker* OR marker*) AND (prognos*) AND (microRNA OR miRNA)" from PubMed. We considered only the researches which take the expression of microRNAs as prognostic biomarkers.
Since we compared the prognostic features of microRNAs in human blood and tissues, articles about microRNA biomarkers in other body fluid such as gastric juice and other animal samples were excluded. Altogether, as prognostic markers, 14 microRNAs in blood and 36 microRNAs in tissues from 45 studies were compared according to their association with clinicopathological features of GC and survival analysis (See Tables 1 and 2). We also summarized the validated targets of given microRNAs in GC by searching databases, such as, TarBase [21], miR2Disease [22], and miRTarBase [23]. In each database, we just considered the terms which studied gastric cancer of Homo sapiens. In TarBase, the terms with prediction score larger than 0.8 were included. In miRTarBase, we only selected the reports based on 'strong evidence'. This review provides complementary to the previous reviews and essential information that will help discover non-invasive biomarkers in prognosis of GC.

Table 1. MicroRNA biomarkers in blood for gastric cancer.

\begin{tabular}{|c|c|c|c|c|c|c|}
\hline ID & Sample & Features & Poor Survival & Expression & Reference & Validated Targets \\
\hline miR-122 & $\begin{array}{l}96 \mathrm{GC} \\
7 \mathrm{BGC} \\
10 \mathrm{CG} \\
36 \mathrm{HC}\end{array}$ & Distance metastases & Down & Down & Chen et al.[68] & - \\
\hline miR-17-5p & $\begin{array}{l}79 \text { PRE GC } \\
30 \text { POST GC } \\
6 \text { relapse GC }\end{array}$ & $\begin{array}{l}\text { Differentiation } \\
\text { TNM stages }\end{array}$ & Up & $\mathrm{Up}^{1}$ & Wang et al.[30] & - \\
\hline miR-18a & $\begin{array}{l}82 \mathrm{GC} \\
65 \mathrm{HC}\end{array}$ & $\begin{array}{l}\text { LNM } \\
\text { Pathological grade }\end{array}$ & $\mathrm{Up}^{*}$ & Up & Su et al. [66] & - \\
\hline miR-20a & $\begin{array}{l}79 \text { PRE GC } \\
30 \text { POST GC } \\
6 \text { relapse GC }\end{array}$ & $\begin{array}{l}\text { Differentiation } \\
\text { TNM stages }\end{array}$ & Up & $\mathrm{Up}^{1}$ & Wang et al.[30] & - \\
\hline miR-200c & $\begin{array}{l}67 \mathrm{GC} \\
15 \mathrm{HC}\end{array}$ & LNM & Up & $\mathrm{Up}$ & Valladares-Ayerbes et al.[64] & BCL2, XIAP[99] \\
\hline miR-203 & $\begin{array}{l}154 \mathrm{GC} \\
22 \mathrm{HC}\end{array}$ & $\begin{array}{l}\text { Gender } \\
\text { Lymphatic invasion } \\
\text { Venous invasion } \\
\text { Peritoneal metastasis } \\
\text { Distance metastasis } \\
\text { LNM } \\
\text { Liver metastasis } \\
\text { TNM stage }\end{array}$ & Down & Down & Imaoka et al. [28] & - \\
\hline $\operatorname{miR}-21$ & $69 \mathrm{GC}$ & Venous invasion & $\mathrm{Up}^{*}$ & - & Komatsu et al.[26] & $\begin{array}{l}\text { RECK[92] } \\
\text { PTEN[100] } \\
\text { Serpini1[101] }\end{array}$ \\
\hline miR-21 & $\begin{array}{l}42 \text { PRE GC } \\
42 \text { POST GC }\end{array}$ & $\begin{array}{l}\text { Differentiation } \\
\text { LNM }\end{array}$ & - & $\mathrm{Up}^{1}$ & Ma et al.[27] & $\begin{array}{l}\text { RECK[92] } \\
\text { PTEN[100] } \\
\text { Serpini1[101] }\end{array}$ \\
\hline $\operatorname{miR}-218$ & $\begin{array}{l}68 \mathrm{GC} \\
56 \mathrm{HC}\end{array}$ & $\begin{array}{l}\text { Metastasis } \\
\text { Tumor stage }\end{array}$ & Down & Down & Xin et al.[69] & ECOP[102] \\
\hline $\operatorname{miR}-221$ & $\begin{array}{l}82 \mathrm{GC} \\
46 \text { dysplasia } \\
128 \text { SG or CAG }\end{array}$ & Differentiation & - & $\mathrm{Up}$ & Song et al.[31] & $\begin{array}{l}\text { p27, p57 [103] } \\
\text { PTEN[104] }\end{array}$ \\
\hline miR-222 & $\begin{array}{l}114 \mathrm{GC} \\
36 \mathrm{CAG} \\
56 \mathrm{HC}\end{array}$ & LNM & Up & Up & Fu et al.[65] & $\begin{array}{l}\text { p27, p57 [103] } \\
\text { PTEN[104] } \\
\text { RECK[105] }\end{array}$ \\
\hline miR-25 & $\begin{array}{l}\text { Tissue: } \\
33 \text { GC } \\
33 \text { HC } \\
\text { Blood: } \\
70 \text { GC } \\
70 \text { HC }\end{array}$ & $\begin{array}{l}\text { LNM } \\
\text { TNM stage }\end{array}$ & Up & $\mathrm{Up}$ & Li et al.[70] & $\begin{array}{l}\text { p57 [103] } \\
\text { BCL2L11[106] } \\
\text { FBXW7[46] }\end{array}$ \\
\hline miR-27a & $82 \mathrm{GC}$ & Metastasis & Up & Up & Huang et al.[67] & Prohibitin [107] \\
\hline
\end{tabular}




\begin{tabular}{|c|c|c|c|c|c|c|}
\hline & & Recurrent & & & & APC[108] \\
\hline $\operatorname{miR}-376 \mathrm{c}$ & $\begin{array}{l}82 \text { GC } \\
46 \text { dysplasia } \\
128 \text { SG or CAG }\end{array}$ & Differentiation & - & $\mathrm{Up}$ & Song et al.[31] & - \\
\hline miR-744 & $\begin{array}{l}82 \text { GC } \\
46 \text { dysplasia } \\
128 \text { SG or CAG }\end{array}$ & Differentiation & - & $\mathrm{Up}$ & Song et al.[31] & - \\
\hline
\end{tabular}

Table 2. MicroRNA biomarkers in tissues for gastric cancer.

\begin{tabular}{|c|c|c|c|c|c|c|}
\hline$\overline{\text { ID }}$ & Sample & Features & Poor Survival & Expression & Reference & Validated Targets \\
\hline miR-107 & $\begin{array}{l}161 \text { GC } \\
161 \text { ANTT }\end{array}$ & $\begin{array}{l}\text { Invasion } \\
\text { LNM } \\
\text { Tumor stage }\end{array}$ & $\mathrm{Up}$ & $\mathrm{Up}$ & Inoue et al. [41] & $\begin{array}{l}\text { CDK6[40] } \\
\text { DICER1[41] }\end{array}$ \\
\hline miR-1207-5p & $\begin{array}{l}23 \mathrm{GC} \text { with LNM } \\
23 \mathrm{GC} \text { without LNM }\end{array}$ & $\begin{array}{l}\text { LNM Lymphovascular invasion } \\
\text { Stromal reaction type } \\
\text { TNM stage }\end{array}$ & - & Down ${ }^{1}$ & Huang et al. [53] & - \\
\hline miR-125a-3p & $\begin{array}{l}70 \text { GC } \\
70 \text { ANTT }\end{array}$ & $\begin{array}{l}\text { Invasion } \\
\text { LNM } \\
\text { Liver metastasis } \\
\text { Tumor stage } \\
\text { Tumor size } \\
\text { Peritoneal dissemination }\end{array}$ & Down & Down & Hashiguchi et al. [48] & - \\
\hline miR-125a-5p & $87 \mathrm{GC}$ & $\begin{array}{l}\text { Invasion depth } \\
\text { Liver metastasis } \\
\text { Tumor stage } \\
\text { Tumor size }\end{array}$ & Down & Down ${ }^{4}$ & Nishida et al. [47] & ERBB2[47] \\
\hline miR-130a & $\begin{array}{l}41 \text { GC } \\
41 \text { ANTT }\end{array}$ & $\begin{array}{l}\text { Metastasis } \\
\text { Invasion } \\
\text { Proliferation }\end{array}$ & $\mathrm{Up}$ & Up & Jiang et al. [45] & RUNX3[45] \\
\hline miR-141 & $\begin{array}{l}36 \text { GC } \\
36 \text { ANTT }\end{array}$ & $\begin{array}{l}\text { Invasion } \\
\text { Proliferation } \\
\text { Metastasis }\end{array}$ & - & Down & Zuo et al. [54] & - \\
\hline miR-142-5p & $\begin{array}{l}29 \text { REGC } \\
36 \text { non-REGC }\end{array}$ & Recurrence & Up & Down ${ }^{2}$ & Zhang et al. [76] & - \\
\hline miR-143 & $\begin{array}{l}138 \mathrm{GC} \\
30 \mathrm{NTT}\end{array}$ & $\begin{array}{l}\text { Tumor stage } \\
\text { Scirrhous type }\end{array}$ & $\mathrm{Up}^{*}$ & Up & Naito et al. [73] & - \\
\hline miR-145 & $\begin{array}{l}138 \text { GC } \\
30 \text { NTT }\end{array}$ & $\begin{array}{l}\text { Tumor stage } \\
\text { Scirrhous type }\end{array}$ & $\mathrm{Up}^{*}$ & Up & Naito et al. [74] & $\mathrm{CDH} 2[109]$ \\
\hline miR-148a & $\begin{array}{l}106 \text { GC } \\
106 \text { ANTT }\end{array}$ & $\begin{array}{l}\text { Distant metastasis } \\
\text { Organ invasion } \\
\text { Peritoneal invasion }\end{array}$ & Down & Down & Tseng et al. [50] & $\begin{array}{l}\text { DNMT1[110] } \\
\text { p27[111] } \\
\text { ROCK1 [63] }\end{array}$ \\
\hline miR-153 & $\begin{array}{l}80 \text { GC } \\
80 \text { ANTT }\end{array}$ & $\begin{array}{l}\text { Invasion } \\
\text { LNM } \\
\text { Migration }\end{array}$ & Down & Down & Zhang et al [55] & - \\
\hline miR-181c & $103 \mathrm{GC}$ & $\begin{array}{l}\text { Differentiation } \\
\text { Invasive depth } \\
\text { Tumor stage }\end{array}$ & $\mathrm{Up}$ & $\mathrm{Up}^{4}$ & Cui et al. [32] & $\begin{array}{l}\text { NOTCH4, } \\
\text { KRAS[112] } \\
\text { BCL2[113] }\end{array}$ \\
\hline miR-192 & $\begin{array}{l}118 \text { GC } \\
118 \text { ANTT }\end{array}$ & $\begin{array}{l}\text { Tumor sizes } \\
\text { Borrmann type }\end{array}$ & - & Down ${ }^{3}$ & Chiang et al [61] & - \\
\hline miR-192 & $\begin{array}{l}38 \text { GC } \\
38 \text { ANTT }\end{array}$ & LNM & - & Up & Xu et al. [62] & - \\
\hline miR-193b & $\begin{array}{l}48 \text { GC } \\
48 \text { ANTT }\end{array}$ & $\begin{array}{l}\text { Differentiation } \\
\text { Lauren type } \\
\text { Tumor stage } \\
\text { Invasion } \\
\text { Metastasis }\end{array}$ & Down & Down & Mu et al. [35] & - \\
\hline miR-195 & $45 \mathrm{GC}$ & Recurrence & - & $\mathrm{Up}^{2}$ & Brenner et al. [75] & - \\
\hline miR-196a & $\begin{array}{l}109 \text { GC } \\
20 \text { ANTT }\end{array}$ & $\begin{array}{l}\text { Invasion depth } \\
\text { Serosal invasion } \\
\text { Lymphatic invasion } \\
\text { LNM } \\
\text { Distant metastasis } \\
\text { TNM stage } \\
\text { Peritoneal seeding } \\
\text { Gross type } \\
\text { Lauren subtype }\end{array}$ & $\mathrm{Up}$ & Up & Tsai et al. [44] & radixin[44] \\
\hline miR-196a & $\begin{array}{l}48 \text { GC } \\
48 \text { ANTT }\end{array}$ & Differentiation & $\mathrm{Up}$ & Up & Mu et al. [35] & - \\
\hline miR-196a-5p & $\begin{array}{l}58 \text { GC } \\
58 \text { ANTT }\end{array}$ & $\begin{array}{l}\text { LNM } \\
\text { TNM stage }\end{array}$ & $\mathrm{Up}$ & Up & Li et al. [58] & - \\
\hline miR-199a-3p & $45 \mathrm{GC}$ & Recurrence & - & $\mathrm{Up}^{2}$ & Brenner et al. [75] & SMARCA2 [114] \\
\hline miR-199a-5p & $28 \mathrm{GC}$ & Metastasis & - & Up & Zhao et al. [60] & MAP3K11 [115] \\
\hline
\end{tabular}




\begin{tabular}{|c|c|c|c|c|c|c|}
\hline & $\begin{array}{l}48 \text { GC LNM } \\
25 \text { NTT }\end{array}$ & & & & & $\begin{array}{l}\text { Smad4[116] } \\
\text { SMARCA2 [114] }\end{array}$ \\
\hline miR-196b & $\begin{array}{l}109 \text { GC } \\
20 \text { ANTT }\end{array}$ & $\begin{array}{l}\text { Invasion depth } \\
\text { Serosal invasion } \\
\text { Lymphatic invasion } \\
\text { LNM } \\
\text { Distant metastasis } \\
\text { TNM stage } \\
\text { Peritoneal seeding } \\
\text { Gross type }\end{array}$ & Up & $\mathrm{Up}$ & Tsai et al. [44] & - \\
\hline miR-206 & $\begin{array}{l}98 \text { GC } \\
98 \text { ANTT }\end{array}$ & $\begin{array}{l}\text { Venous invasion } \\
\text { LNM } \\
\text { Hematogenous recurrence } \\
\text { pStage }\end{array}$ & Down & Down & Yang et al. [51] & CCND2[117] \\
\hline $\mathrm{miR}-20 \mathrm{~b}$ & $\begin{array}{l}102 \mathrm{GC} \\
102 \mathrm{ANTT}\end{array}$ & $\begin{array}{l}\text { LNM } \\
\text { Distance metastasis } \\
\text { TNM stage }\end{array}$ & Up & $\mathrm{Up}$ & Xue et al. [59] & - \\
\hline miR-21 & $\begin{array}{l}56 \text { GC without LNM } \\
30 \text { GC with LNM } \\
72 \text { ANTT }\end{array}$ & $\begin{array}{l}\text { Differentiation } \\
\text { LNM }\end{array}$ & Up & $\mathrm{Up}$ & Xu et al. [33] & $\begin{array}{l}\text { RECK[92] } \\
\text { PTEN[100] } \\
\text { Serpini1[101] }\end{array}$ \\
\hline miR-215 & $\begin{array}{l}118 \text { GC } \\
118 \text { ANTT }\end{array}$ & $\begin{array}{l}\text { Borrmann type } \\
\text { Tumor sizes } \\
\text { pT stage }\end{array}$ & - & Down ${ }^{3}$ & Chiang et al [61] & - \\
\hline miR-215 & $\begin{array}{l}38 \text { GC } \\
38 \text { ANTT }\end{array}$ & - & - & Up & Xu et al. [62] & - \\
\hline miR-217 & $\begin{array}{l}83 \text { GC } \\
83 \text { ANTT }\end{array}$ & $\begin{array}{l}\text { Differentiation Distant metastasis } \\
\text { Invasion } \\
\text { Tumor size } \\
\text { TNM stag }\end{array}$ & Down & Down & Chen et al. [36] & - \\
\hline miR-22 & $\begin{array}{l}98 \text { GC } \\
98 \text { ANTT }\end{array}$ & $\begin{array}{l}\text { LNM } \\
\text { Distant metastasis } \\
\text { pStage }\end{array}$ & Down & Down & Yang et al. [51] & SP1[118] \\
\hline $\mathrm{miR}-23 \mathrm{a} / \mathrm{b}$ & $\begin{array}{l}160 \mathrm{GC} \\
160 \mathrm{ANTT}\end{array}$ & $\begin{array}{l}\text { Invasion } \\
\text { LNM } \\
\text { TNM stage }\end{array}$ & Up & $\mathrm{Up}$ & Ma et al. [43] & IL6R[119] \\
\hline miR-25 & $\begin{array}{l}40 \mathrm{GC} \\
40 \mathrm{ANTT}\end{array}$ & $\begin{array}{l}\text { Invasion } \\
\text { Proliferation } \\
\text { LNM } \\
\text { Migration }\end{array}$ & Up & Up & Gong et al [46] & $\begin{array}{l}\text { p57 [103] } \\
\text { BCL2L11[106] } \\
\text { FBXW7[46] }\end{array}$ \\
\hline $\operatorname{miR}-29 c$ & $\begin{array}{l}115 \text { GC } \\
115 \text { ANTT }\end{array}$ & $\begin{array}{l}\text { Venous invasion } \\
\text { TNM stage }\end{array}$ & - & Down & Gong et al. [52] & - \\
\hline miR-335 & $\begin{array}{l}31 \text { REGC } \\
43 \text { non-REGC }\end{array}$ & Recurrence & Up & $\mathrm{Up}^{2}$ & Yan et al. [77] & - \\
\hline $\operatorname{miR}-34 a$ & $\begin{array}{l}137 \mathrm{GC} \\
137\end{array}$ & $\begin{array}{l}\text { Lymph node involvement } \\
\text { TNM stage } \\
\text { Differentiation } \\
\text { Tumor recurrence }\end{array}$ & Down & Down & Zhang et al. [34] & BCL2[120] \\
\hline $\operatorname{miR}-375$ & $\begin{array}{l}29 \text { REGC } \\
36 \text { non-REGC }\end{array}$ & Recurrence & Up & $\mathrm{Up}^{2}$ & Zhang et al. [76] & $\begin{array}{l}\text { PDK1, YWHAZ[121] } \\
\text { JAK2[122] }\end{array}$ \\
\hline $\operatorname{miR}-451$ & $45 \mathrm{GC}$ & Recurrence & $\mathrm{Up}^{*}$ & $\mathrm{Up}^{2}$ & Brenner et al. [75] & MIF [123] \\
\hline miR-520d-3p & $\begin{array}{l}120 \mathrm{GC} \\
120 \mathrm{ANTT}\end{array}$ & $\begin{array}{l}\text { Invasion depth } \\
\text { LNM } \\
\text { Tumor stage }\end{array}$ & Down & Down & Li et al. [49] & - \\
\hline miR-630 & $\begin{array}{l}236 \mathrm{GC} \\
236 \mathrm{ANTT}\end{array}$ & $\begin{array}{l}\text { Invasion } \\
\text { LNM } \\
\text { Distant metastasis } \\
\text { TNM stage. }\end{array}$ & Up & Up & Chu et al. [42] & - \\
\hline miR-92a & $97 \mathrm{GC}$ & Tumor growth & Up & - & Wu et al. [78] & - \\
\hline
\end{tabular}

\section{Clinicopathological features}

We summarized and discussed the association between GC clinicopathological features and microRNAs biomarkers in blood and tissues. The clinicopathological features were generally classified into five groups including differentiation, invasion, metastasis, tumor stages and others, these are related to the important cancer 2hallmarks [24, 25] (See Figure 1).

We first compared the number of clinicopathological factors that correlated with the microRNAs in blood and tissues. As shown in Figure 2(a), 42.86\% of the blood microRNAs significantly correlated with one and two clinicopathological factors. Only two microRNAs (14.29\%) significantly correlated with 
three or more than three factors: miR-21strongly correlated with venous invasion, differentiation and lymph node metastasis [26, 27] and miR-203 correlated with gender, invasion, metastasis, TNM stage [28]. Conversely, tissues-based microRNAs tend to correlated with more clinicopathological factors. Nearly $60 \%$ microRNAs in tissues were significantly associated with more than three clinicopathological factors and only $25 \%$ microRNAs were associated with one factor.

\section{Differentiation}

In histology, tumor was classified as three degrees of differentiation: well, moderate and poor dif- ferentiation according to WHO classification [29]. Patients with well-differentiated tumors usually carry a better prognosis whereas patients with poorly differentiated tumors carry a worse prognosis. There are six circulating microRNA biomarkers associated with differentiation and all of them were up-regulated in poor differentiation group, including miR-17-5p, miR-20a, miR-21, miR-221, miR-376c and miR-744 [27, 30, 31], whereas in tissue samples, miR-181c, miR-196a and miR-21, were up-regulated and miR-193b, miR-217 and miR-34a, were down-regulated in poor differential groups [32-36].
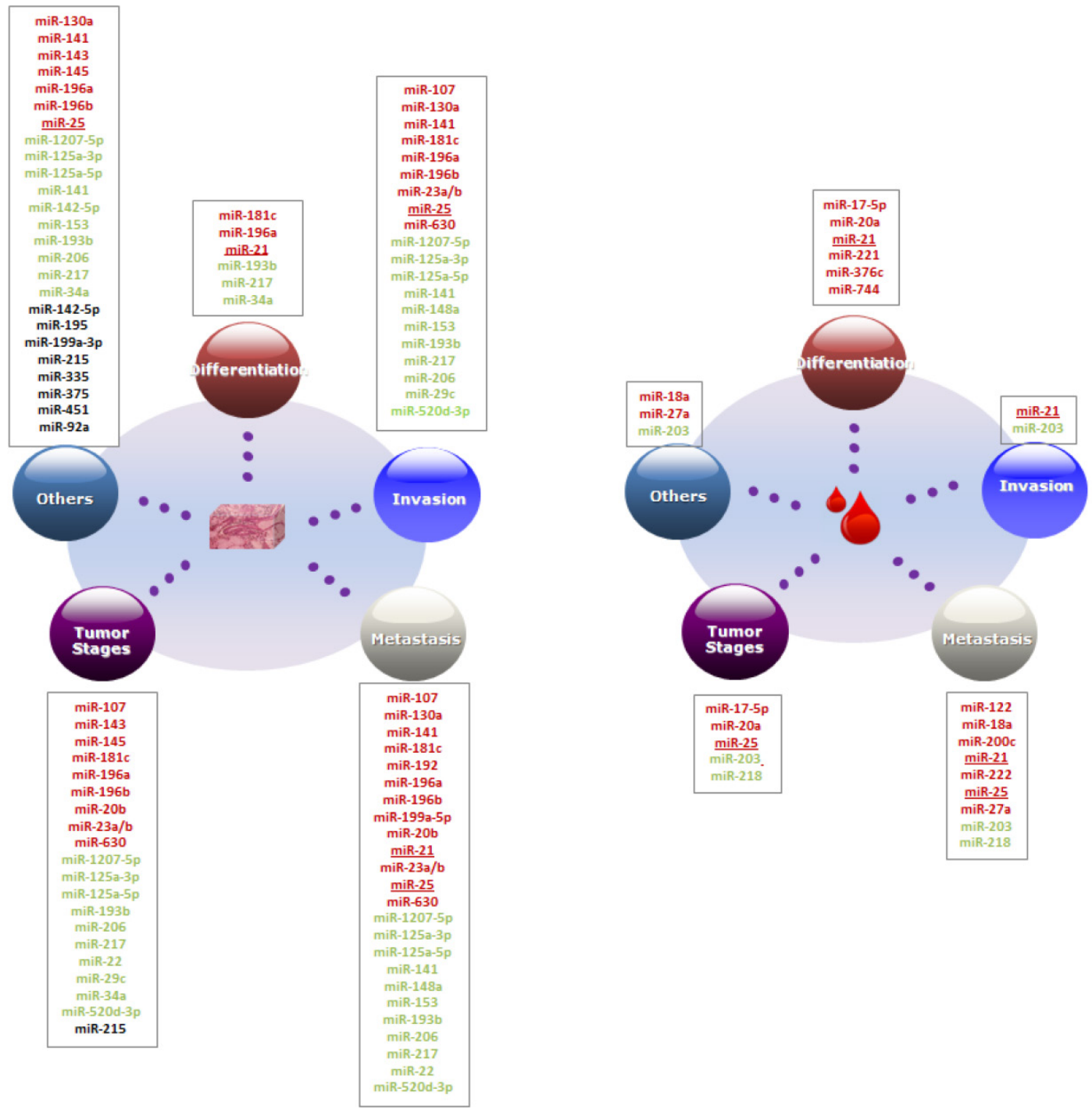

Figure 1. Association between clinicopathological features and microRNA biomarkers. MicroRNAs in red and green denote the up-regulated and down-regulated expression in GC. MicroRNAs in black denote that the microRNAs were differentially expressed between two-sample groups other than GC patient and healthy controls, e.g. between recurrence and non-recurrence groups. microRNAs marked with underline present the microRNAs could be prognostic markers both in tissues and blood. 
a

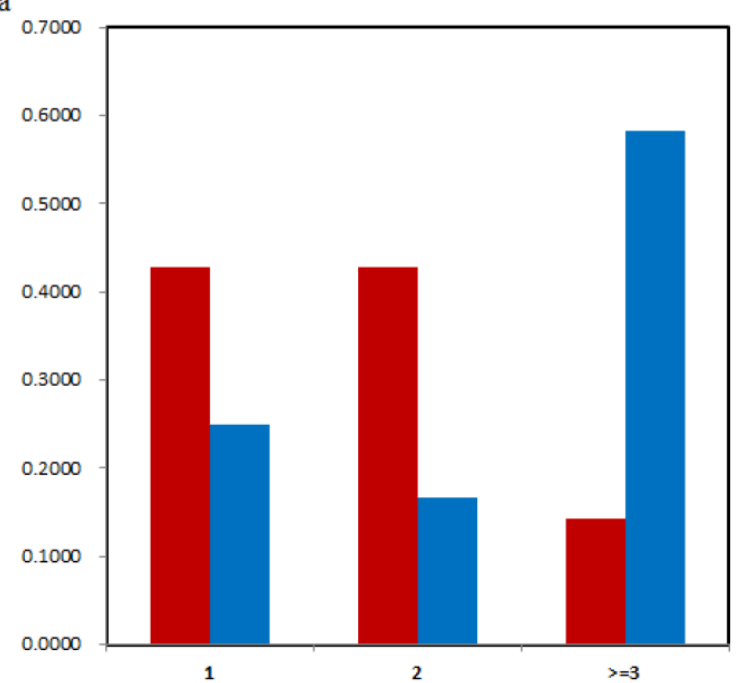

$\mathrm{b}$

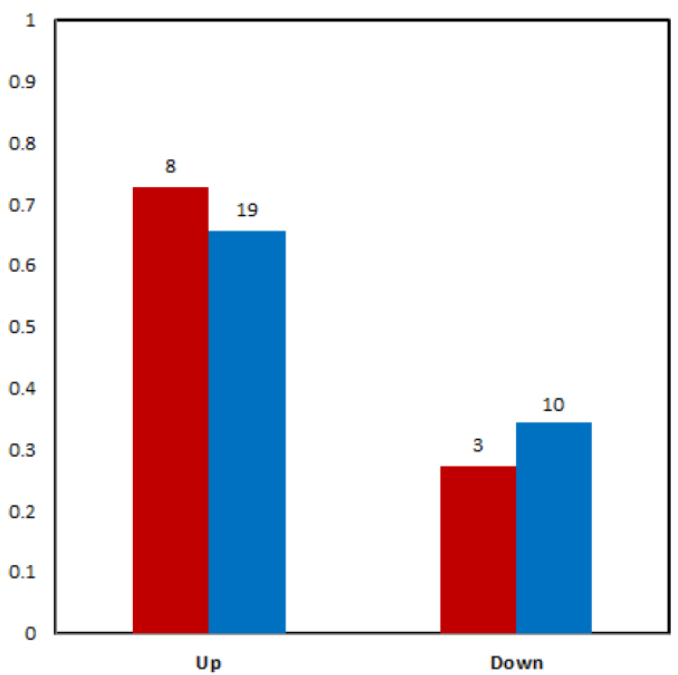

c

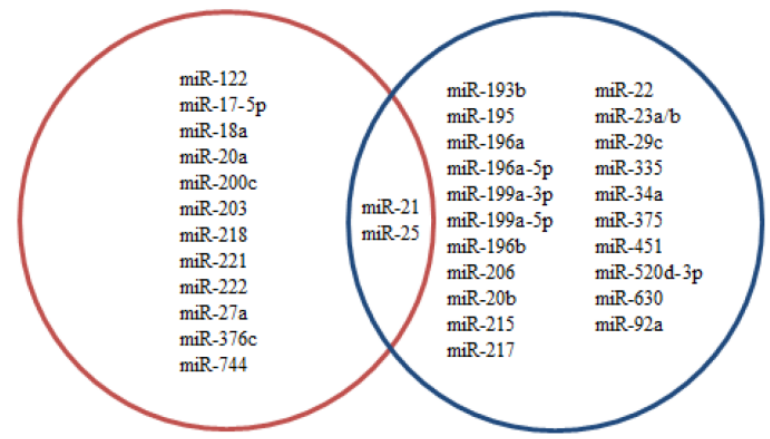

Figure 2. (a) Distribution of the number of clinicopathological features correlated with microRNAs. X axis is the number of clinicopathological features. $Y$ axis is the percent of microRNAs in blood or tissues that correlated with different number of features. (b) Distribution of expression pattern of microRNA biomarkers from blood and tissues with poor survival of GC patients. Red is the microRNAs from blood and blue is from tissues. Numbers above the bars are the number of microRNA biomarkers in corresponding group. (c) The Venn diagram for microRNA prognostic biomarkers in blood and tissue. Blue and red circles represent microRNAs in tissue and blood respectively.

\section{Invasion}

GC invasion is a process when tumor cells invade the tumor nearby tissues and vasculature. It is an elementary factor that affects patient survival rate and the most important step of tumor cells dissemination and metastasis in different types of cancer [37-39]. Zhao et al. had reviewed the role of microRNAs in the GC invasion and metastasis [39]. Some of the microRNAs could be as prognostic biomarkers. miR-107, for example, is a potential prognostic biomarker in tissue and inhibits the GC cells invasion by directly targeting the cyclin-dependent kinase 6 (CDK6) [40, 41]. In tissue, expression levels of miR-181c, miR-630 and co-expression of miR-23a and miR-23b were strongly associated with invasion depth [32, 42, 43]. Increased miR-196a/b expression was significantly correlated with serosal, vascular, lymphatic and depth of invasion but in another study miR-196a doesn't have such significantly association with depth of invasion one-way analysis of variance [35, 44]. High expression of miR-130a and miR-25 promoted the migration, invasion and proliferation of gastric cancer cells by targeting RUNX3 and FBXW7, respectively $[45,46]$.

Decreased expression of eight microRNAs were associated with different types of invasion, e.g. miR-125-3p/-5p and miR-520d-3p with depth of invasion [47-49], miR-148a with organ invasion and peritoneal invasion [50], miR-29c and miR-206 with venous invasion [51, 52]. Patients with down-regulated miR-1207- $5 p$ had more lymphovascular invasion [53]. Down regulation of miR-141 promoted cell proliferation, invasion and migration in AGS GC cell lines [54]. Suppression of miR-153 also promoted GC cell migration and invasion by inhibiting SNAI1-induced epithelial-mesenchymal transition (EMT) [55]. In blood, however, only two microRNAs miR-21 and miR-203 in blood was associated with invasion $[26,28]$.

\section{Metastasis}

Metastasis, a complex and multi-step process, is a primary clinicopathological feature of advanced GC. In metastasis, cancer cells migrate from the primary neoplasm to a distant location and proliferate to form 
anther macroscopic tumors [56, 57]. However, the mechanisms that regulate metastasis remain poorly understood.

In tissues, lymph node metastasis (LNM) was significantly related with higher expression of miR-107, miR-181c, miR-196a/b, miR-20b, miR-23a/b, miR-25 and miR-630 [32, 41-44, 46, 58, 59]. Increased $\mathrm{miR}-196 \mathrm{a} / \mathrm{b}, \mathrm{miR}-20 \mathrm{~b}$ and miR-630 expression were also more detected in GC with distant metastasis. miR-196a/b simulates cell metastasis through direct negative regulation of radixin in GC [42, 44]. High-level of miR-199a-5p expression could promote cell metastasis in GC cells since suppression of miR-199a-5p decreased the metastatic ability in GC cells in vitro and in vivo [60]. Moreover, there are controversial results about miR-196a, -215 and -192 . As mentioned above, miR-196a was reported significantly up-regulated in distance metastasis [44] and correlated with lymph node metastasis [58] while no such correlation was found in the subsequent study.[35] . Chiang et al. found there were no significant difference in the expression levels of these miR-215 and -192 between GC tissue and non-tumor tissue and both of them were decreased in the GC cell lines [61]. But $\mathrm{Xu}$ and Fan found that miR-215 and -192 levels were increased in GC tissue and related with lymph node metastasis [62].

With regard to down-regulated microRNAs in GC tissues, reduced expression of miR-125-3p, miR-153, miR-206, miR-22 and miR-520d-3p were strongly correlated with lymph node metastasis [48, 49, 51, 55]. MiR-1207-5p was significantly down-regulated in samples with LNM compared with those without LNM [53]. Additionally, expression levels of miR-125-3p, miR-5p, miR-148a and miR-22 were associated with distance metastasis, especially the correlation between liver metastasis and miR-125-3p/-5p [47, 48, 50, 51]. miR-217 was significantly down-regulated in patients with liver metastasis and lung metastasis and promoted tumor progression and metastasis in vivo experiment [36]. miR-148a inhabits the GC cell metastasis by reducing the mRNA and protein levels of ROCK1 in GC [63]. miR-141expression level was found to be decreased in primary tumors that subsequently metastasized compared with those that did not metastasize [54].

Several circulating microRNA biomarkers also displayed significantly correlation with metastasis. The expression level of miR-18a, miR-203, miR-200c and miR-222 was significantly correlated with the number of lymph node metastases [28, 64-66]. Increased expression levels of miR-27a in plasma were significantly correlated with poor overall survival for metastatic or recurrent GC [67]. miR-122 was significantly lower in GC with distant metastasis than healthy controls and GC with no distant metastasis [68]. miR-218 was found to be associated with tumor metastasis and decreased in metastasis than non-metastasis and normal serum [69].

Two microRNAs, miR-25 and miR-21 have the same expression pattern in tissue and blood. The miR-25 expression was elevated both in plasma and tissues of GC patients with tumor node metastasis stage or lymph node metastasis [70]. Although miR-21 in plasma of Japan GC patients was not associated with metastasis [26], its expression in plasma of post-operative patients in China was highly associated with lymph node metastasis rate [27] and was higher in tissues of GC patients with lymph node metastasis than those without lymph node metastasis [33].

\section{Tumor Stages}

The TNM (tumor-node-metastasis) classification is a widely used cancer staging systems based on the size and extension of the primary tumor $(\mathrm{T})$, nearby lymph nodes involvement $(\mathrm{N})$, and the presence of or otherwise of distant metastatic spread (M). Recently, the seventh edition of the TNM classification was published which introduced many changes for gastric cancer, especially the $\mathrm{N}$ stage reclassification $[71,72]$.

In tissues, high expression of miR-107, -181c, $-196 a / b,-20 b,-23 a / b$ and -630 was more frequently to be detected in GC with advanced tumor stage [32, 41-44, 59]. In particular, as a potential prognostic biomarker of scirrhous type GC miR-143 and -145 expression levels were higher in scirrhous type GC than non- scirrhous type GC and strongly correlated with tumor stage and scirrhous type histology $[73,74]$. GC patients with low expression of miR-125-3p, -125-5p, $-193 b,-206,-217,-22,-29 c,-34 a,-520 d-3 p$ were more often found at advanced tumor stage [34-36, 47-49, 51, 52].

In blood, miR-17-5p, $-20 a,-203,-25$ and -28 were significantly associated with TNM staging classification system. Expression levels of miR-17-5p and miR-20a were only significantly higher in TNM III stage group than I and II group [30] and the level of miR-25 was higher both in TNM III and IV than I and II [70], while miR-218 and miR-203 were decreased in the TNM later stages III and IV [28, 69].

\section{Other clinicopathological features}

Beyond the above four main clinicopathological features, microRNA biomarkers are also related with other clinicopathological features, such as GC histological classification, recurrence, tumor growth, tumor size, etc. miR-143 and miR-145 were associated with scirrhous type histology [73, 74]. miR-196a was more frequently detected in diffuse and infiltrative 
GC subtype [44]. Brenner et al. found that miR-451, -199a-3p and -195 expression were increased in GC patients with recurrence than patients without recurrence after all the patients received tumor resected surgery [75]. Zhang and colleagues identified that miR-375 and miR-142-5p were differentially expressed between recurrence groups and non-recurrence groups and the combination of these two microRNAs could recognize the above groups both in the training and test samples as a classifier [76]. Recently, high expression level of miR-335 was also detected in high recurrence groups and it was involved in several oncogenic pathways such as TP53, TGF- $\beta$ and Wnt [77]. Improving miR-90a expression promoted tumor growth in vitro and in vivo [78].

\section{Survival analysis}

Prediction of survival is one of the main functions of the prognostic biomarkers. As shown in Figure 2(b), Table 1 and Table 2, we summarize the correlation between patients' survival and expression levels of microRNA biomarkers from blood and tissues. Up-regulated microRNAs were more significantly correlated with poor survival than down-regulated ones, both in blood and tissues. In blood, high concentration of 6 microRNAs (miR-17-5p, -20a, -200c, -222, -25 and -27a) and low concentration of 3 microRNAs (miR-122, miR-203 and -218) were significantly associated with worse overall survival [28, 30, 64, 65, 67-70]. High expression of miR-18a in plasma was associated with shorter both disease-free and disease-specific survival of GC patients [66]. Post-operative patients with increased miR-21 levels had a significantly worse prognosis (disease-specific survival) than those with decreased expression levels [26]. In tissues, increased levels of 13 (miR-107, -130a, -142-5p, -181c, -196a, -196b, -20b, -21, $-25,-335,-375,-630$ and $-92 a)$ and 3 (miR-143, -145 and -451) microRNAs were correlated with overall poor survival and disease specific survival rates separately while decreased expression of 10 microRNAs (miR-125a-3p, -125a-5p, -153, -193b, -148a, -206, -217, $-22,-34 a$ and $-520 d-3 p)$ were correlated significantly with overall poorer survival rates [32-36, 41, 42, 44-51, $55,59,73-78]$.

\section{Enrichment analysis of targets of prog- nostic microRNA biomarkers}

To further explore different functions of the above microRNA biomarkers in tissue and blood, we performed enrichment analysis of their target genes by Ingenuity Pathways Analysis (IPA $\left.{ }^{\circledR}\right)$. The targets of microRNAs were collected from experimentally validated database miRecords [79], TarBase [21], miR2Disease [22], and miRTarBase [23] or predicted by computational software tools HOCTAR [80], ExprTargetDB [81], and starBase [82] as reported in our previous research [5]. For the 36 microRNA biomarkers in GC tissue, 3735 target genes were predicted and 199 pathways were significantly enriched by their targets $(p<0.01) .2093$ targets were predicted for 14 microRNA biomarkers in blood and significantly enriched in 134 pathways $(\mathrm{p}<0.01)$. More than half of the enriched pathways by targets of microRNAs in tissue and in blood are overlapped, as see in Figure 3 (a). As shown in Table 3 and Figure 3 (b) and (c), the top 10 significantly enriched pathways by the targets of the given microRNAs in blood and tissue were listed. Among the top 10 enriched pathways, four of them are same as molecular mechanisms of cancer, p53 signaling, chronic myeloid leukemia signaling and Wnt/ $\beta$-catenin Signaling. In the case of tissue, several in the top ten pathways are related with epithelial cell or tissue such as regulation of the epithelial-mesenchymal transition pathway [83], epithelial adherens junction signaling and germ cell-sertoli cell junction signaling. The function is different for the top 10 pathways that enriched by target genes of blood based microRNA markers. There are not so many pathways related to epithelial cell or tissue, but most of them play important roles in GC such as AMPK signaling, which was reported to induce apoptosis through the mitochondrial apoptotic pathway [84, 85], Wnt signaling, the one is well-known for promoting the development of hematoendothelial cell [86-89], and IGF-1 Signaling which induces epithelial-mesenchymal transition in gastric cancer $[90,91]$.

We then calculated the percentage of mapped targets of the microRNA in the top ten pathways and listed the top three microRNAs in Table 3. In the case of blood, miR-200c and miR-21 are in the top three in every pathway whereas in tissue, miR-21 is in the top three in eight pathways. This indicates that miR-21 plays a pivotal role in the development of gastric cancer $[92,93]$. Additionally, in each of the four overlapped pathways, the top three microRNAs are not the same. Take molecular mechanisms of cancer as an example, miR-200c and miR-23b are in the top three ones in blood and tissue respectively besides miR-21 and miR-25.

\section{Conclusions}

In this review, we made a comparison of the prognostic abilities for microRNA in blood and tissues. There are almost twice as many prognostic microRNA biomarkers in tissues as in blood. This may be due to more studies investigating microRNAs from tissues. Another important reason is that microRNAs may be released into the blood selectively [94, 95]. Although some microRNAs display the same expres- 
sion pattern in blood and tissues, they correlate with different clinicopathological features. miR-21 for example, is associated with invasion in blood but not in tissue. Most of microRNAs in blood were significantly correlated with no more than two clinicopathological features while microRNAs in tissues were associated with more features. Both in blood and tissues, microRNAs could be strongly associated with survival and most of the microRNAs with high expression level were detected in the poor survival groups.

Table 3. Top 10 significantly enriched pathways by targets of microRNA biomarker from GC blood and tissue.

\begin{tabular}{|c|c|c|c|c|}
\hline Source & Ingenuity Canonical Pathways & p-value & Ratio & miRNA \\
\hline \multirow[t]{10}{*}{ Blood } & Molecular Mechanisms of Cancer & $1.00 \mathrm{E}-11$ & 0.39 & miR-200c, miR-21, miR-25 \\
\hline & Glucocorticoid Receptor Signaling & $6.76 \mathrm{E}-09$ & 0.37 & miR-200c, miR-21, miR-25 \\
\hline & IGF-1 Signaling & $2.95 \mathrm{E}-08$ & 0.48 & miR-200c, miR-21, miR-221 \\
\hline & Wnt $/ \beta$-catenin Signaling & $6.46 \mathrm{E}-08$ & 0.43 & miR-25, miR-21, miR-200c \\
\hline & Pancreatic Adenocarcinoma Signaling & $1.12 \mathrm{E}-07$ & 0.48 & miR-21, miR-200c, miR-20a \\
\hline & AMPK Signaling & $1.35 \mathrm{E}-07$ & 0.40 & miR-200c, miR-21, miR-25 \\
\hline & p53 Signaling & 2.82E-07 & 0.46 & miR-21, miR-200c, miR-20a \\
\hline & 14-3-3-mediated Signaling & 3.09E-07 & 0.44 & miR-200c, miR-221, miR-21 \\
\hline & Chronic Myeloid Leukemia Signaling & $5.13 \mathrm{E}-07$ & 0.46 & miR-20a, miR-200c, miR-21 \\
\hline & Myc Mediated Apoptosis Signaling & $5.50 \mathrm{E}-07$ & 0.56 & miR-20a, miR-200c, miR-21 \\
\hline \multirow[t]{10}{*}{ Tissue } & $\underline{\text { Molecular Mechanisms of Cancer }}$ & $3.98 \mathrm{E}-16$ & 0.59 & miR-21, miR-25, miR-23b \\
\hline & Germ Cell-Sertoli Cell Junction Signaling & 7.94E-14 & 0.69 & miR-141, miR-23b, miR-21 \\
\hline & PI3K/AKT Signaling & $2.51 \mathrm{E}-11$ & 0.70 & miR-22, miR-23b, miR-195 \\
\hline & Epithelial Adherens Junction Signaling & 7.94E-11 & 0.65 & miR-23b, miR-21, miR-141 \\
\hline & p53 Signaling & 3.89E-10 & 0.70 & miR-23b, miR-21, miR-141 \\
\hline & Mouse Embryonic Stem Cell Pluripotency & 4.17E-10 & 0.73 & miR-143, miR-451a, miR-21 \\
\hline & HGF Signaling & 8.32E-10 & 0.68 & miR-21, miR-23b, miR-196b \\
\hline & Wnt $/ \beta$-catenin Signaling & 2.14E-09 & 0.61 & miR-141, miR-25, miR-34a \\
\hline & Chronic Myeloid Leukemia Signaling & 2.29E-09 & 0.69 & miR-21, miR-34a, miR-22 \\
\hline & Regulation of the Epithelial-Mesenchymal Transition Pathway & 2.88E-09 & 0.62 & miR-141, miR-21, miR-22 \\
\hline
\end{tabular}

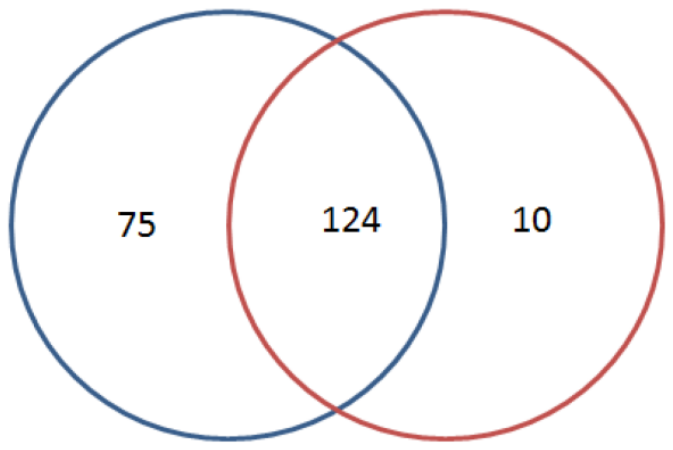

b

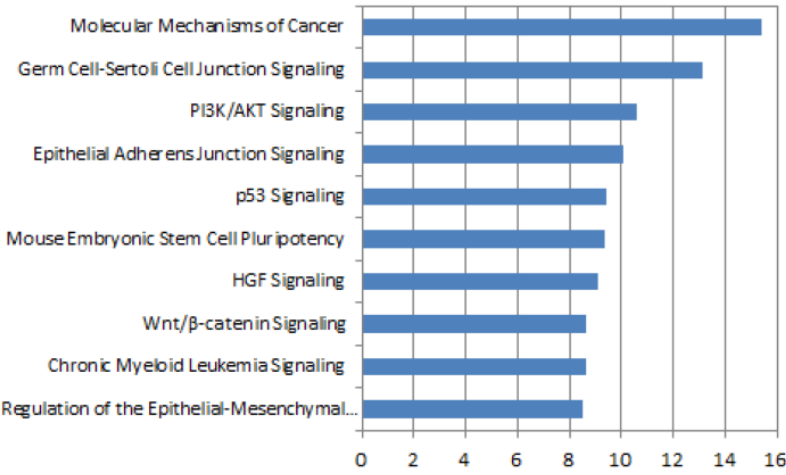

C

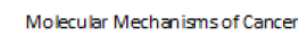

Gucocorticoid Receptor Signaling

IGF-1 Signaling

Wnt/B-catenin Signaling

Pancr eatic Adenocar cinomaSignaling

AMPK Signaling

p53 Signaling

14-3-3-mediated Signaling

Chronic Myebid Leukemia Signaling

Myc Mediated Apoptosis Signaling

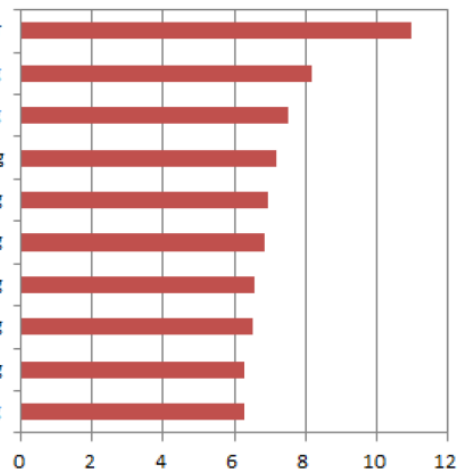

Figure 3 Enrichment analyses of target genes of microRNA biomarkers in tissue and blood. (a) The Venn diagram for numbers of significantly enriched pathways. The blue and red circles represent pathways enriched by targets of microRNAs in tissue and blood respectively. (b) Top 10 significantly enriched pathways by targets of microRNA biomarker from GC tissue. (c) Top 10 significantly enriched pathways by targets of microRNA biomarker from GC blood. 
Gastric cancer with a very poor prognosis remains to account for considerable amount of morbidity and mortality in the world. MicroRNAs in blood are promising biomarkers since they are non-invasive and could have a possible clinical application in GC. As well-known that GC is heterogeneous and personalized, the understanding of the roles of microRNAs in GC progression needs further exploration at systems biological level [96-98].

\section{Competing Interests}

The authors have declared that no competing interest exists.

\section{Acknowledgments}

National Natural Science Foundation of China grants (31470821, 31170795, 31400712, 91230117), Special Funding for Life and Health Researches from Science and Technology Department of Jiangsu Province (BL2014046), Natural Science Foundation for Colleges and Universities in Jiangsu Province (13KJB180021) and Natural Science Foundation of USTS (XKQ201315), Technology R\&D Program of Suzhou (SYN201409).

\section{References}

1. Hamilton JP, Meltzer SJ. A review of the genomics of gastric cancer. Clin Gastroenterol Hepatol. 2006; 4: 416-25

2. Ferlay J, Shin HR, Bray F, Forman D, Mathers C, Parkin DM. Estimates of worldwide burden of cancer in 2008: GLOBOCAN 2008. Int J Cancer. 2010; 127: 2893-917.

3. Meyer HJ, Wilke H. Treatment strategies in gastric cancer. Dtsch Arztebl Int. 2011; 108: 698-705; quiz 6

4. Wohrer SS, Raderer M, Hejna M. Palliative chemotherapy for advanced gastric cancer. Ann Oncol. 2004; 15: 1585-95.

5. Zhang $W$, Zang J, Jing X, Sun Z, Yan W, Yang D, et al. Identification of candidate miRNA biomarkers from miRNA regulatory network with application to prostate cancer. J Transl Med. 2014; 12: 66.

6. Chen J, Zhang D, Zhang W, Tang Y, Yan W, Guo L, et al. Clear cell renal cell carcinoma associated microRNA expression signatures identified by an integrated bioinformatics analysis. J Transl Med. 2013; 11: 169.

7. Huang J, Sun Z, Yan W, Zhu Y, Lin Y, Chen J, et al. Identification of microRNA as sepsis biomarker based on miRNAs regulatory network analysis. Biomed Res Int. 2014; 2014: 594350

8. Yan $\mathrm{W}, \mathrm{Xu} \mathrm{L}$, Sun Z, Lin Y, Zhang W, Chen J, et al. MicroRNA biomarker identification for pediatric acute myeloid leukemia based on a novel bioinformatics model. Oncotarget. 2015.

9. Wang JL, Hu Y, Kong X, Wang ZH, Chen HY, Xu J, et al. Candidate microRNA biomarkers in human gastric cancer: a systematic review and validation study. PLoS One. 2013; 8: e73683.

10. Shrestha S, Hsu SD, Huang WY, Huang HY, Chen W, Weng SL, et al. A systematic review of microRNA expression profiling studies in human gastric cancer. Cancer Med. 2014: 3: 878-88.

11. Li J, Jin H, Wang X. Epigenetic biomarkers: potential applications in gastrointestinal cancers. ISRN Gastroenterol. 2014; 2014: 464015.

12. Toiyama Y, Okugawa Y, Goel A. DNA methylation and microRNA biomarkers for noninvasive detection of gastric and colorectal cancer. Biochem Biophys Res Commun. 2014; 455: 43-57.

13. Zhu X, Lv M, Wang H, Guan W. Identification of circulating microRNAs as novel potential biomarkers for gastric cancer detection: a systematic review and meta-analysis. Dig Dis Sci. 2014; 59: 911-9.

14. Wang F, Sun GP, Zou YF, Hao JQ, Zhong F, Ren WJ. MicroRNAs as promising biomarkers for gastric cancer. Cancer Biomark. 2012: 11: 259-67.

15. Tong F, Cao P, Yin Y, Xia S, Lai R, Liu S. MicroRNAs in gastric cancer: from benchtop to bedside. Dig Dis Sci. 2014; 59: 24-30.

16. Wu HH, Lin WC, Tsai KW. Advances in molecular biomarkers for gastric cancer: miRNAs as emerging novel cancer markers. Expert Rev Mol Med. 2014; 16: e1.

17. Shin VY, Chu KM. MiRNA as potential biomarkers and therapeutic targets for gastric cancer. World J Gastroenterol. 2014; 20: 10432-9.
18. Jiang $\mathrm{C}$, Chen $\mathrm{X}$, Alattar $\mathrm{M}$, Wei J, Liu H. MicroRNAs in tumorigenesis, metastasis, diagnosis and prognosis of gastric cancer. Cancer Gene Ther. 2015; 22: 291-301.

19. Liu HS, Xiao HS. MicroRNAs as potential biomarkers for gastric cancer. World J Gastroenterol. 2014; 20: 12007-17.

20. Wang QX, Zhu YQ, Zhang $\mathrm{H}$, Xiao J. Altered MiRNA expression in gastric cancer: a systematic review and meta-analysis. Cell Physiol Biochem. 2015; 35: 933-44.

21. Sethupathy P, Corda B, Hatzigeorgiou AG. TarBase: A comprehensive database of experimentally supported animal microRNA targets. RNA. 2006; 12: $192-7$.

22. Jiang $Q$, Wang $Y$, Hao $Y$, Juan L, Teng M, Zhang X, et al. miR2Disease: a manually curated database for microRNA deregulation in human disease. Nucleic Acids Res. 2009; 37: D98-104.

23. Hsu SD, Lin FM, Wu WY, Liang C, Huang WC, Chan WL, et al. miRTarBase: a database curates experimentally validated microRNA-target interactions. Nucleic Acids Res. 2011; 39: D163-9.

24. Hanahan D, Weinberg RA. The hallmarks of cancer. Cell. 2000; 100: 57-70.

25. Floor SL, Dumont JE, Maenhaut C, Raspe E. Hallmarks of cancer: of all cancer cells, all the time? Trends Mol Med. 2012; 18: 509-15.

26. Komatsu S, Ichikawa D, Tsujiura M, Konishi $H$, Takeshita $H$, Nagata $H$, et al. Prognostic impact of circulating miR-21 in the plasma of patients with gastric carcinoma. Anticancer Res. 2013; 33: 271-6.

27. Ma GJ, Gu RM, Zhu M, Wen X, Li JT, Zhang YY, et al. Plasma post-operative miR-21 expression in the prognosis of gastric cancers. Asian Pac J Cancer Prev. 2013; 14: 7551-4

28. Imaoka $\mathrm{H}$, Toiyama $\mathrm{Y}$, Okigami $\mathrm{M}$, Yasuda $\mathrm{H}$, Saigusa $\mathrm{S}$, Ohi $\mathrm{M}$, et al. Circulating microRNA-203 predicts metastases, early recurrence, and poor prognosis in human gastric cancer. Gastric Cancer. 2015.

29. Bosman FT, Organization WH, Carneiro F, Hruban RH. WHO Classification of Tumours of the Digestive System: International Agency for Research on Cancer (I A R C) (UN). 2010.

30. Wang M, Gu H, Wang S, Qian H, Zhu W, Zhang L, et al. Circulating miR-17-5p and miR-20a: molecular markers for gastric cancer. Mol Med Rep. 2012; 5: 1514-20.

31. Song MY, Pan KF, Su HJ, Zhang L, Ma JL, Li JY, et al. Identification of serum microRNAs as novel non-invasive biomarkers for early detection of gastric cancer. PLoS One. 2012; 7: e33608

32. Cui M, Yue L, Fu Y, Yu W, Hou X, Zhang X. Association of microRNA-181c expression with the progression and prognosis of human gastric carcinoma. Hepatogastroenterology. 2013; 60: 961-4.

33. Xu Y, Sun J, Xu J, Li Q, Guo Y, Zhang Q. miR-21 Is a Promising Novel Biomarker for Lymph Node Metastasis in Patients with Gastric Cancer. Gastroenterol Res Pract. 2012; 2012: 640168.

34. Zhang H, Li S, Yang J, Liu S, Gong X, Yu X. The prognostic value of miR-34a expression in completely resected gastric cancer: tumor recurrence and overall survival. Int J Clin Exp Med. 2015; 8: 2635-41.

35. Mu YP, Tang S, Sun WJ, Gao WM, Wang M, Su XL. Association of miR-193b down-regulation and miR-196a up-regulation with clinicopathological features and prognosis in gastric cancer. Asian Pac J Cancer Prev. 2014; 15: 8893-900.

36. Chen DL, Zhang DS, Lu YX, Chen LZ, Zeng ZL, He MM, et al. microRNA-217 inhibits tumor progression and metastasis by downregulating EZH2 and predicts favorable prognosis in gastric cancer. Oncotarget. 2015; 6: 10868-79.

37. Hippo $Y$, Yashiro $M$, Ishii $M$, Taniguchi $H$, Tsutsumi $S$, Hirakawa $K$, et al. Differential gene expression profiles of scirrhous gastric cancer cells with high metastatic potential to peritoneum or lymph nodes. Cancer Res. 2001; 61: 889-95.

38. Yoshida K, Yamaguchi K, Okumura N, Osada S, Takahashi T, Tanaka Y, et al. The roles of surgical oncologists in the new era: minimally invasive surgery for early gastric cancer and adjuvant surgery for metastatic gastric cancer. Pathobiology. 2011; 78: 343-52.

39. Zhao $\mathrm{X}, \mathrm{Li} \mathrm{X}, \mathrm{Yuan} \mathrm{H}$. microRNAs in gastric cancer invasion and metastasis. Front Biosci (Landmark Ed). 2013; 18: 803-10.

40. Feng L, Xie Y, Zhang H, Wu Y. miR-107 targets cyclin-dependent kinase 6 expression, induces cell cycle G1 arrest and inhibits invasion in gastric cancer cells. Med Oncol. 2012; 29: 856-63.

41. Inoue T, Iinuma H, Ogawa E, Inaba T, Fukushima R. Clinicopathological and prognostic significance of microRNA-107 and its relationship to DICER1 mRNA expression in gastric cancer. Oncol Rep. 2012; 27: 1759-64.

42. Chu D, Zhao Z, Li Y, Li J, Zheng J, Wang W, et al. Increased microRNA-630 expression in gastric cancer is associated with poor overall survival. PLoS One. 2014; 9: e90526.

43. Ma G, Dai W, Sang A, Yang X, Gao C. Upregulation of microRNA-23a/b promotes tumor progression and confers poor prognosis in patients with gastric cancer. Int J Clin Exp Pathol. 2014; 7: 8833-40.

44. Tsai MM, Wang CS, Tsai CY, Chen CY, Chi HC, Tseng YH, et al. MicroRNA-196a/-196b promote cell metastasis via negative regulation of radixin in human gastric cancer. Cancer Lett. 2014; 351: 222-31.

45. Jiang H, Yu WW, Wang LL, Peng Y. miR-130a acts as a potential diagnostic biomarker and promotes gastric cancer migration, invasion and proliferation by targeting RUNX3. Oncol Rep. 2015.

46. Gong J, Cui Z, Li L, Ma Q, Wang Q, Gao Y, et al. MicroRNA-25 promotes gastric cancer proliferation, invasion, and migration by directly targeting F-box and WD-40 Domain Protein 7, FBXW7. Tumour Biol. 2015. 
47. Nishida N, Mimori $\mathrm{K}$, Fabbri $\mathrm{M}$, Yokobori $\mathrm{T}$, Sudo $\mathrm{T}$, Tanaka $\mathrm{F}$, et al. MicroRNA-125a-5p is an independent prognostic factor in gastric cancer and inhibits the proliferation of human gastric cancer cells in combination with trastuzumab. Clin Cancer Res. 2011; 17: 2725-33.

48. Hashiguchi Y, Nishida N, Mimori K, Sudo T, Tanaka F, Shibata K, et al. Down-regulation of miR-125a-3p in human gastric cancer and its clinicopathological significance. Int J Oncol. 2012; 40: 1477-82.

49. Li R, Yuan W, Mei W, Yang K, Chen Z. MicroRNA 520d-3p inhibits gastric cancer cell proliferation, migration, and invasion by downregulating EphA2 expression. Mol Cell Biochem. 2014; 396: 295-305.

50. Tseng $\mathrm{CW}$, Lin $\mathrm{CC}$, Chen $\mathrm{CN}$, Huang HC, Juan HF. Integrative network analysis reveals active microRNAs and their functions in gastric cancer. BMC Syst Biol. 2011; 5: 99.

51. Yang Q, Zhang C, Huang B, Li H, Zhang R, Huang Y, et al. Downregulation of microRNA-206 is a potent prognostic marker for patients with gastric cancer. Eur J Gastroenterol Hepatol. 2013; 25: 953-7.

52. Gong J, Li J, Wang $\mathrm{Y}$, Liu C, Jia H, Jiang $\mathrm{C}$, et al. Characterization of microRNA-29 family expression and investigation of their mechanistic roles in gastric cancer. Carcinogenesis. 2014; 35: 497-506.

53. Huang KH, Lan YT, Fang WL, Chen JH, Lo SS, Li AF, et al. The correlation between miRNA and lymph node metastasis in gastric cancer. Biomed Res Int. 2015; 2015: 543163

54. Zuo QF, Zhang R, Li BS, Zhao YL, Zhuang Y, Yu T, et al. MicroRNA-141 inhibits tumor growth and metastasis in gastric cancer by directly targeting transcriptional co-activator with PDZ-binding motif, TAZ. Cell Death Dis. 2015; 6: e1623.

55. Zhang Z, Sun J, Bai Z, Li H, He S, Chen R, et al. MicroRNA-153 acts as a prognostic marker in gastric cancer and its role in cell migration and invasion. Onco Targets Ther. 2015; 8: 357-64.

56. Fidler IJ. The pathogenesis of cancer metastasis: the 'seed and soil' hypothesis revisited. Nat Rev Cancer. 2003; 3: 453-8.

57. Gupta GP, Massague J. Cancer metastasis: building a framework. Cell. 2006; 127: 679-95.

58. Li HL, Xie SP, Yang YL, Cheng YX, Zhang Y, Wang J, et al. Clinical significance of upregulation of mir-196a-5p in gastric cancer and enriched KEGG pathway analysis of target genes. Asian Pac J Cancer Prev. 2015; 16: 1781-7.

59. Xue TM, Tao LD, Zhang M, Xu GC, Zhang J, Zhang PJ. miR-20b overexpression is predictive of poor prognosis in gastric cancer. Onco Targets Ther. 2015; 8: 1871-6.

60. Zhao X, He L, Li T, Lu Y, Miao Y, Liang S, et al. SRF expedites metastasis and modulates the epithelial to mesenchymal transition by regulating miR-199a-5p expression in human gastric cancer. Cell Death Differ. 2014; 21: 1900-13.

61. Chiang Y, Zhou X, Wang Z, Song Y, Liu Z, Zhao F, et al. Expression levels of microRNA-192 and -215 in gastric carcinoma. Pathol Oncol Res. 2012; 18: 585-91.

62. Xu YJ, Fan Y. MiR-215/192 participates in gastric cancer progression. Clin Transl Oncol. 2014

63. Zheng B, Liang L, Wang C, Huang S, Cao X, Zha R, et al. MicroRNA-148a suppresses tumor cell invasion and metastasis by downregulating ROCK1 in gastric cancer. Clin Cancer Res. 2011; 17: 7574-83.

64. Valladares-Ayerbes $M$, Reboredo $M$, Medina-Villaamil V, Iglesias-Diaz $P$, Lorenzo-Patino MJ, Haz M, et al. Circulating miR-200c as a diagnostic and prognostic biomarker for gastric cancer. J Transl Med. 2012; 10: 186.

65. Fu Z, Qian F, Yang X, Jiang H, Chen Y, Liu S. Circulating miR-222 in plasma and its potential diagnostic and prognostic value in gastric cancer. Med Oncol. 2014; 31: 164.

66. Su ZX, Zhao J, Rong ZH, Wu YG, Geng WM, Qin CK. Diagnostic and prognostic value of circulating miR-18a in the plasma of patients with gastric cancer. Tumour Biol. 2014; 35: 12119-25.

67. Huang D, Wang H, Liu R, Li H, Ge S, Bai M, et al. miRNA27a is a biomarker for predicting chemosensitivity and prognosis in metastatic or recurrent gastric cancer. J Cell Biochem. 2014; 115: 549-56.

68. Chen Q, Ge X, Zhang Y, Xia H, Yuan D, Tang Q, et al. Plasma miR-122 and miR-192 as potential novel biomarkers for the early detection of distant metastasis of gastric cancer. Oncol Rep. 2014; 31: 1863-70.

69. Xin SY, Feng XS, Zhou LQ, Sun JJ, Gao XL, Yao GL. Reduced expression of circulating microRNA-218 in gastric cancer and correlation with tumor invasion and prognosis. World J Gastroenterol. 2014; 20: 6906-11.

70. Li BS, Zuo QF, Zhao YL, Xiao B, Zhuang Y, Mao XH, et al. MicroRNA-25 promotes gastric cancer migration, invasion and proliferation by directly targeting transducer of ERBB2, 1 and correlates with poor survival. Oncogene. 2014:0.

71. Sobin LH, Gospodarowicz MK, Wittekind C. TNM Classification of Malignant Tumours: Wiley. 2011.

72. Washington K. 7th edition of the AJCC cancer staging manual: stomach. Ann Surg Oncol. 2010; 17: 3077-9.

73. Naito Y, Sakamoto N, Oue N, Yashiro M, Sentani K, Yanagihara K, et al. MicroRNA-143 regulates collagen type III expression in stromal fibroblasts of scirrhous type gastric cancer. Cancer Sci. 2014; 105: 228-35.

74. Naito Y, Yasuno K, Tagawa H, Sakamoto N, Oue N, Yashiro M, et al. MicroRNA-145 is a potential prognostic factor of scirrhous type gastric cancer. Oncol Rep. 2014; 32: 1720-6.
75. Brenner $\mathrm{B}$, Hoshen MB, Purim $\mathrm{O}$, David MB, Ashkenazi $\mathrm{K}$, Marshak $\mathrm{G}$, et al. MicroRNAs as a potential prognostic factor in gastric cancer. World J Gastroenterol. 2011; 17: 3976-85.

76. Zhang X, Yan Z, Zhang J, Gong L, Li W, Cui J, et al. Combination of hsa-miR-375 and hsa-miR-142-5p as a predictor for recurrence risk in gastric cancer patients following surgical resection. Ann Oncol. 2011; 22: 2257-66.

77. Yan Z, Xiong Y, Xu W, Gao J, Cheng Y, Wang Z, et al. Identification of hsa-miR-335 as a prognostic signature in gastric cancer. PLoS One. 2012; 7: e40037.

78. Wu Q, Yang Z, Wang F, Hu S, Yang L, Shi Y, et al. MiR-19b/20a/92a regulates the self-renewal and proliferation of gastric cancer stem cells. J Cell Sci. 2013; 126: 4220-9.

79. Xiao F, Zuo Z, Cai G, Kang S, Gao X, Li T. miRecords: an integrated resource for microRNA-target interactions. Nucleic Acids Res. 2009; 37: D105-10.

80. Gennarino VA, Sardiello M, Avellino R, Meola N, Maselli V, Anand S, et al. MicroRNA target prediction by expression analysis of host genes. Genome Res. 2009; 19: 481-90.

81. Gamazon ER, Im HK, Duan S, Lussier YA, Cox NJ, Dolan ME, et al. Exprtarget: an integrative approach to predicting human microRNA targets. PLoS One. 2010; 5: e13534.

82. Yang JH, Li JH, Shao P, Zhou H, Chen YQ, Qu LH. starBase: a database for exploring microRNA-mRNA interaction maps from Argonaute CLIP-Seq and Degradome-Seq data. Nucleic Acids Res. 2011; 39: D202-9.

83. Liu YW, Sun M, Xia R, Zhang EB, Liu XH, Zhang ZH, et al. LincHOTAIR epigenetically silences miR34a by binding to PRC2 to promote the epithelial-to-mesenchymal transition in human gastric cancer. Cell Death Dis. 2015; 6: e1802.

84. Saitoh M, Nagai K, Nakagawa K, Yamamura T, Yamamoto S, Nishizaki T. Adenosine induces apoptosis in the human gastric cancer cells via an intrinsic pathway relevant to activation of AMP-activated protein kinase. Biochem Pharmacol. 2004; 67: 2005-11.

85. Yi B, Liu D, He M, Li Q, Liu T, Shao J. Role of the ROS/AMPK signaling pathway in tetramethylpyrazine-induced apoptosis in gastric cancer cells. Oncol Lett. 2013; 6: 583-9.

86. Woll PS, Morris JK, Painschab MS, Marcus RK, Kohn AD, Biechele TL, et al. Wnt signaling promotes hematoendothelial cell development from human embryonic stem cells. Blood. 2008; 111: 122-31.

87. Mao J, Fan S, Ma W, Fan P, Wang B, Zhang J, et al. Roles of Wnt/beta-catenin signaling in the gastric cancer stem cells proliferation and salinomycin treatment. Cell Death Dis. 2014; 5: e1039.

88. Oguma K, Oshima H, Oshima M. Inflammation, tumor necrosis factor and Wnt promotion in gastric cancer development. Future Oncol. 2010; 6: 515-26.

89. Chiurillo MA. Role of the Wnt/beta-catenin pathway in gastric cancer: An in-depth literature review. World J Exp Med. 2015; 5: 84-102.

90. Min $Y$, Adachi $Y$, Yamamoto $H$, Imsumran $A$, Arimura $Y$, Endo $T$, et al Insulin-like growth factor I receptor blockade enhances chemotherapy and radiation responses and inhibits tumour growth in human gastric cancer xenografts. Gut. 2005; 54: 591-600.

91. Li S, Lei X, Zhang J, Yang H, Liu J, Xu C. Insulin-like growth factor 1 promotes growth of gastric cancer by inhibiting foxo1 nuclear retention. Tumour Biol. 2015.

92. Zhang Z, Li Z, Gao C, Chen P, Chen J, Liu W, et al. miR-21 plays a pivotal role in gastric cancer pathogenesis and progression. Lab Invest. 2008; 88: 1358-66.

93. Wan X, Ding X, Chen S, Song H, Jiang H, Fang Y, et al. The functional sites of miRNAs and lncRNAs in gastric carcinogenesis. Tumour biology : the journal of the International Society for Oncodevelopmental Biology and Medicine. 2015; 36: 521-32.

94. Pigati L, Yaddanapudi SC, Iyengar R, Kim DJ, Hearn SA, Danforth D, et al. Selective release of microRNA species from normal and malignant mammary epithelial cells. PLoS One. 2010; 5: e13515.

95. Chen TS, Lai RC, Lee MM, Choo AB, Lee CN, Lim SK. Mesenchymal stem cell secretes microparticles enriched in pre-microRNAs. Nucleic Acids Res. 2010; 38: $215-24$

96. Chen J, Wang Y, Shen B, Zhang D. Molecular signature of cancer at gene level or pathway level? Case studies of colorectal cancer and prostate cancer microarray data. Comput Math Methods Med. 2013; 2013: 909525.

97. Wang Y, Chen J, Li Q, Wang H, Liu G, Jing Q, et al. Identifying novel prostate cancer associated pathways based on integrative microarray data analysis. Comput Biol Chem. 2011; 35: 151-8.

98. Chen J, Sun M, Shen B. Deciphering oncogenic drivers: from single genes to integrated pathways. Brief Bioinform. 2015; 16: 413-28.

99. Zhu W, Xu H, Zhu D, Zhi H, Wang T, Wang J, et al miR-200bc/429 cluster modulates multidrug resistance of human cancer cell lines by targeting BCL2 and XIAP. Cancer Chemother Pharmacol. 2012; 69: 723-31.

100. Zhang BG, Li JF, Yu BQ, Zhu ZG, Liu BY, Yan M. microRNA-21 promotes tumor proliferation and invasion in gastric cancer by targeting PTEN. Oncol Rep. 2012; 27: 1019-26.

101. Yamanaka S, Olaru AV, An F, Luvsanjav D, Jin Z, Agarwal R, et al. MicroRNA-21 inhibits Serpini1, a gene with novel tumour suppressive effects in gastric cancer. Digestive and liver disease : official journal of the Italian Society of Gastroenterology and the Italian Association for the Study of the Liver. 2012; 44: 589-96.

102. Gao C, Zhang Z, Liu W, Xiao S, Gu W, Lu H. Reduced microRNA-218 expression is associated with high nuclear factor kappa $\mathrm{B}$ activation in gastric cancer. Cancer. 2010; 116: 41-9. 
103. Kim YK, Yu J, Han TS, Park SY, Namkoong B, Kim DH, et al. Functional links between clustered microRNAs: suppression of cell-cycle inhibitors by microRNA clusters in gastric cancer. Nucleic Acids Res. 2009; 37: 1672-81.

104. Chun-Zhi Z, Lei H, An-Ling Z, Yan-Chao F, Xiao Y, Guang-Xiu W, et al. MicroRNA-221 and microRNA-222 regulate gastric carcinoma cell proliferation and radioresistance by targeting PTEN. BMC Cancer. 2010; 10: 367.

105. Li N, Tang B, Zhu ED, Li BS, Zhuang Y, Yu S, et al. Increased miR-222 in H. pylori-associated gastric cancer correlated with tumor progression by promoting cancer cell proliferation and targeting RECK. FEBS Lett. 2012; 586: 722-8.

106. Petrocca F, Visone R, Onelli MR, Shah MH, Nicoloso MS, de Martino I, et al. E2F1-regulated microRNAs impair TGFbeta-dependent cell-cycle arrest and apoptosis in gastric cancer. Cancer Cell. 2008; 13: 272-86.

107. Liu T, Tang H, Lang Y, Liu M, Li X. MicroRNA-27a functions as an oncogene in gastric adenocarcinoma by targeting prohibitin. Cancer Lett. 2009; 273 : 233-42.

108. Zhang Z, Liu S, Shi R, Zhao G. miR-27 promotes human gastric cancer cell metastasis by inducing epithelial-to-mesenchymal transition. Cancer Genet. 2011; 204: 486-91.

109. Gao P, Xing AY, Zhou GY, Zhang TG, Zhang JP, Gao C, et al. The molecular mechanism of microRNA-145 to suppress invasion-metastasis cascade in gastric cancer. Oncogene. 2013; 32: 491-501.

110. Zhu A, Xia J, Zuo J, Jin S, Zhou H, Yao L, et al. MicroRNA-148a is silenced by hypermethylation and interacts with DNA methyltransferase 1 in gastric cancer. Med Oncol. 2012; 29: 2701-9.

111. Guo SL, Peng Z, Yang X, Fan KJ, Ye H, Li ZH, et al. miR-148a promoted cell proliferation by targeting p27 in gastric cancer cells. Int J Biol Sci. 2011; 7: 567-74.

112. Hashimoto Y, Akiyama Y, Otsubo T, Shimada S, Yuasa Y. Involvement of epigenetically silenced microRNA-181c in gastric carcinogenesis. Carcinogenesis. 2010; 31: 777-84.

113. Zhu W, Shan X, Wang T, Shu Y, Liu P. miR-181b modulates multidrug resistance by targeting BCL2 in human cancer cell lines. Int J Cancer. 2010; 127: 2520-9.

114. Sakurai K, Furukawa C, Haraguchi T, Inada K, Shiogama K, Tagawa T, et al. MicroRNAs miR-199a-5p and $-3 p$ target the Brm subunit of SWI/SNF to generate a double-negative feedback loop in a variety of human cancers. Cancer Res. 2011; 71: 1680-9.

115. Song G, Zeng H, Li J, Xiao L, He Y, Tang Y, et al. miR-199a regulates the tumor suppressor mitogen-activated protein kinase kinase kinase 11 in gastric cancer. Biol Pharm Bull. 2010; 33: 1822-7.

116. Zhang Y, Fan KJ, Sun Q, Chen AZ, Shen WL, Zhao ZH, et al. Functional screening for miRNAs targeting Smad4 identified miR-199a as a negative regulator of TGF-beta signalling pathway. Nucleic Acids Res. 2012; 40: 9286-97.

117. Zhang L, Liu X, Jin H, Guo X, Xia L, Chen Z, et al. miR-206 inhibits gastric cancer proliferation in part by repressing cyclinD2. Cancer Lett. 2013; 332: 94-101.

118. Guo MM, Hu LH, Wang YQ, Chen P, Huang JG, Lu N, et al. miR-22 is down-regulated in gastric cancer, and its overexpression inhibits cell migration and invasion via targeting transcription factor Sp1. Med Oncol. 2013; 30: 542.

119. Zhu LH, Liu T, Tang H, Tian RQ, Su C, Liu M, et al. MicroRNA-23a promotes the growth of gastric adenocarcinoma cell line MGC803 and downregulates interleukin-6 receptor. FEBS J. 2010; 277: 3726-34.

120. Ji Q, Hao X, Meng Y, Zhang M, Desano J, Fan D, et al. Restoration of tumor suppressor miR-34 inhibits human p53-mutant gastric cancer tumorspheres. BMC Cancer. 2008; 8: 266.

121. Tsukamoto Y, Nakada C, Noguchi T, Tanigawa M, Nguyen LT, Uchida T, et al. MicroRNA-375 is downregulated in gastric carcinomas and regulates cell survival by targeting PDK1 and 14-3-3zeta. Cancer Res. 2010; 70: 2339-49.

122. Ding L, Xu Y, Zhang W, Deng Y, Si M, Du Y, et al. MiR-375 frequently downregulated in gastric cancer inhibits cell proliferation by targeting JAK2. Cell Res. 2010; 20: 784-93.

123. Bandres E, Bitarte N, Arias F, Agorreta J, Fortes P, Agirre X, et al. microRNA-451 regulates macrophage migration inhibitory factor production and proliferation of gastrointestinal cancer cells. Clin Cancer Res. 2009; 15: 2281-90. 